\title{
POTRET SOSIAL EKONOMI PETANI JAGUNG DAN KEMITRAAN iGrOW DI KABUPATEN GORONTALO
}

\author{
Agustinus Moonti $\left.{ }^{*} 1\right)$, Larasati Sukmadewi Wibowo ${ }^{2)}$ \\ 1),2) Fakultas Pertanian Universitas Negeri Gorontalo \\ ${ }^{*}$ Penulis Korespondensi, E-mail: agustinusmoonti@ung.ac.id
}

\begin{abstract}
ABSTRAK
Tujuan dari penelitian ini adalah untuk mengetahui pemetaan kondisi sosial ekonomi petani jagung sebelum menjadi mitra iGrow. Jenis penelitian ini yaitu deskriptif dengan pendekatan kualitatif yang menggunakan kombinasi data sekunder dan data primer. Pengumpulan data primer dilakukan dengan wawancara terhadap petani jagung yang menjadi mitra iGrow menggunakan kueisioner. Penentuan jumlah sampel dilakukan dengan model proporsional sesuai dengan jumlah populasi wilayah. Jumlah sampel dari keseluruhan wilayah populasi berjumlah 32 orang. Hasil penelitian menunjukkan rata-rata produktivitas lahan jagung jika dikonversi dalam satuan 1 hektar adalah: 2,79 ton sebelum tergabung dalam kemitraan iGrow. rata-rata total pendapatan bersih petani jagung dalam 1 hektar yaitu Rp. 3.332.265. Manfaat kerja sama petani jagung dengan iGrow yaitu: Akses terhadap permodalan menjadi lebih mudah, Pengembalian modal setelah panen tidak dikenakan bunga, Akses terhadap benih dan pupuk menjadi lebih mudah dari biasanya karena difasilitasi oleh iGrow, Peluang petani untuk mendapatkan harga pasar yang lebih baik menjadi terbuka lebar, sebab petani tidak terikat untuk menjual hasil panen, Peluang mendapatkan pendapatan lebih besar, karena beberapa komponen biaya dapat dikurangi seperti biaya pasca panen. Petani dapat memasarkan jagung hasil panen dalam bentuk tongkol, sehingga tidak harus menambah biaya perontokan / rotor. Tahap awal program kemitraan berjalan, pendampingan petani cukup intensif dari pihak iGrow, sehingga petani dapat memperoleh wawasan dan pengetahuan baru.
\end{abstract}

Kata kunci: Petani jagung; Sosial ekonomi; Kemitraan; iGrow

\section{PENDAHULUAN}

Jagung merupakan komoditas unggulan Provinsi Gorontalo telah banyak memberikan kontribusi positif bagi ekonomi daerah. Upaya peningkatan produksi jagung mempunyai peran strategis dalam penguatan ketahanan pangan menuju kemandirian pangan dan peningkatan kesejahteraan petani. Oleh karena itu pemerintah menargetkan swasembada jagung dalam periode 2015-2019 (Kementerian Pertanian, 2015). Menurut data Dinas Pertanian Provinsi Gorontalo (2017), produksi jagung di Gorontalo dalam lima tahun terakhir terus meningkat, dari 644,8 ribu ton pada tahun 2012 menjadi 882,9 ribu ton pada tahun 2016, dengan produktivitas rata-rata $4.87 \mathrm{t} /$ ha/tahun. Bahkan berdasarkan Dinas Pertanian Provinsi Gorontalo, tahun 2017 produksi jagung mencapai 1.5 juta ton. Kuantitas produksi jagung yang semakin meningkat seharusnya juga dapat mempengaruhi sisi pendapatan petani.

Meskipun kuantitas produksi jagung terus mengalami peningkatan, namun salah satu pokok penting dalam pengembangan komoditas jagung di Provinsi Gorontalo yang harus terpenuhi yaitu peningkatan taraf ekonomi petani jagung. Namun secara umum potret keadaan sosial ekonomi petani rata-rata cenderung berada pada level bawah. Persentase penduduk miskin berdasarkan laporan kajian kemiskinan menurut tipologi 
wilayah di Provinsi Gorontalo tahun 2017 oleh Litbang Bappeda Provinsi Gorontalo, ditemukan bahwa mayoritas penduduk miskin berprofesi sebagai petani. Petani miskin tersebut lebih banyak tersebar di wilayah pedesaan dan pesisir yang juga mayoritas hampir 90 persen adalah petani jagung.

Dapat dicermati jika penduduk miskin yang bekerja sebagai petani ternyata masih memiliki persentase terbesar, maka diperlukan upaya konkrit dalam pembangunan pertanian guna memperbaiki keadaan sosial ekonomi petani termasuk petani jagung. Hidayat (2017) yang menyatakan bahwa pembangunan pertanian bertujuan untuk selalu memperbaiki mutu hidup dan kesejahteraan manusia terutama petani, baik perorangan maupun masyarakat pada umumnya. Dalam upaya pembangunan pertanian, kendala utama yang selalu bersinggungan dengan petani adalah pada kegiatan usahatani. Modal yang minim serta sulitnya petani terhadap akses lembaga permodalan, sulitnya akses terhadap saprodi, akses terhadap harga pasar, cengkraman tengkulak, dan minimnya pengetahuan usahatani, merupakan potret masalah yang sering terlihat pada petani. Berdasarkan data kajian kemiskinan menurut tipologi wilayah tahun 2017 oleh Litbang Bappeda Provinsi Gorontalo, terlihat bahwa rata-rata 53,16 persen petani masih mengandalkan modal usahatani dari tengkulak, dan 50,63 persennya menjual hasil panen tetap pada tengkulak.

Model kemitraan merupakan bentuk solusi yang digunakan untuk menjawab berbagai permasalahan dan kendala petani khususnya dalam kegiatan usahatani. Hal ini karena usahatani merupakan akar pokok yang menjadi penentu besar kecilnya pendapatan petani baik petani modern maupun tradisional. Hadirnya pihak-pihak perusahaan yang akan menjadikan petani tradisional sebagai mitra diharapkan dapat memberikan fungsi pemberdayaan bagi petani secara optimal. Berbagai keterbatasan dan kendala yang dihadapi petani jagung saat ini dapat menjadi sasaran utama yang perlu dituntaskan dengan model kemitraan. Tentunya model kemitraan sejatinya akan memberikan manfaat kepada kedua belah pihak antara petani maupun pihak perusahaan mitra. Untuk dapat mengetahui tingkat manfaat tersebut maka perlu dilakukan telaah dan kajian terkait pola kemitraan yang terbangun antara kedua belah pihak. Sebagai bentuk tindak lanjut awal, maka perlu dilakukan pemetaan kondisi sosial ekonomi petani jagung sebelum menjadi mitra perusahaan, yang kemudian akan dikomparasi dengan kondisi sosial ekonomi pasca kemitraan, salah satunya adalah bentuk kemitraan iGrow.

iGrow menghubungkan masyarakat yang ingin menjadi pemberi pembiayaan modal dengan para petani yang menjadi penerima pembiayaan modal untuk bersama-sama meningkatkan skala penanaman/budi daya dan kesejahteraan para pelaku dunia pertanian. Di bumi kita ini, terutama negara seperti Indonesia, ada jutaan hektar lahan tidak optimal yang belum diberdayakan secara optimal, dan juga ada jutaan orang petani yang masih hidup di bawah garis kemiskinan karena hasil pekerjaan yang tidak mencukupi. Sementara kebutuhan dan permintaan masyarakat atas makanan dari produk pertanian terus bertambah dari hari ke hari.

Riset yang dilakukan oleh PBB mengatakan bahwa kita harus meningkatkan lahan pertanian menjadi 2 kali lipat dalam 40 tahun ke depan untuk bisa memenuhi kebutuhan pangan populasi dunia. FAO mengatakan bahwa kebutuhan pangan dunia akan meningkat hingga 70\% karena penambahan 2,3 milyar penduduk dunia di tahun 2050 . Itulah mengapa kita butuh banyak melakukan peningkatan penanaman pangan. iGrow mengidentifikasi tanaman yang punya kebutuhan tinggi di pasar, stabilitas harga dan karakteristik yang baik, lalu kami menghubungkan petani dan lahan yang bisa dipergunakan, kemudian kami membuka peluang pembiayaan penanaman kepada kaum urban, (iGrow Asia, 2020).

iGrow bukanlah semata produk dengan visi komersial saja, tapi juga punya misi besar untuk bisa melestarikan kehidupan di bumi. Menciptakan ketahanan pangan yang dapat diakses secara adil dan merata bagi semua manusia di bumi. Memanfaatkan sumber daya yang kita miliki masing-masing untuk menciptakan perubahan yang lebih baik bagi bumi kita bersama. Penelitian ini bertujuan untuk mengetahui pemetaan kondisi sosial ekonomi petani jagung sebelum menjadi mitra iGrow. 


\section{METODE}

Penelitian ini dilaksanakan pada bulan Mei 2019 yang berlokasi di empat desa yaitu Desa Huntu dan Desa Pilobuhuta Kecamatan Batudaa serta Desa Tabongo Barat dan Desa Motinelo Kecamatan Tabongo Kabupaten Gorontalo. Lokasi penelitian ini tersebar di seluruh petani jagung yang menjalin kemitraan dengan iGrow. Jenis penelitian ini yaitu deskriptif dengan pendekatan kualitatif yang menggunakan kombinasi data sekunder dan data primer. Pengumpulan data primer dilakukan dengan wawancara terhadap petani jagung yang menjadi mitra iGrow menggunakan kueisioner. Penentuan jumlah sampel dilakukan dengan model proporsional, dimana Proporsional sampling adalah pengambilan sampel yang memperhatikan pertimbangan unsur-unsur atau kategori dalam populasi penelitian (Arikunto, 2006). sesuai dengan jumlah populasi wilayah dimana jumlah sampel dari keseluruhan wilayah populasi berjumlah 32 orang, sehingga digunakan jumlah tersebut sebagai sampel dalam penelitian.

Penentuan petani responden yang diwawancarai dilapangan dilakukan dengan metode aksidental sampling. Metode analisis yang digunakan adalah analisis deskriptifkualitatif, untuk mengeksplorasi dan klarifikasi mengenai suatu fenomena atuakenyataan sosial, dengan jalan mendeskripsikan sejumlah variabel yang berkenaan dengan masalah dan uinit yang diteliti. Jenis penelitian ini tidak sampai mempersoalkan jaringan hubungan antar variabel yang ada tidak maksudkan untuk menarik generasi yang menjelaskan variabel-varibel anteseden yang menyebabkan sesuatu gejala atau kenyataan sosial (Lubis, 2015).

Dengan mendeskripsikan data primer yang bersumber dari hasil wawancara dengan petani. Tujuan pendekatan metode deskriptif-kualitatif adalah pencarian fakta dengan interpretasi yang tepat serta membuat penjelasan secara faktual, dan akurat mengenai fakta-fakta dan sifat-sifat populasi.

\section{HASIL DAN PEMBAHASAN}

\section{Gambaran Umum Wilayah}

\section{Luas Wilayah dan Jumlah Penduduk Kecamatan Batudaa dan Tabongo}

Desa Pilobuhuta Kecamatan Batudaan memiliki luas wilayah terbesar dibandingkan desa lainnya. Namun penduduk dengan jumlah terbanyak terdapat didesa Tabongo Barat Kecamatan Tabongo. Desa Huntu dan Desa Pilobuhuta Kecamatan Batudaa awalnya merupakan satu desa, yang kemudian Desa Pilobuhuta dimekarkan dari Desa Huntu. Hal yang sama juga antara Desa Tabongo Barat dan Motinelo, dimana Desa Motinelo merupakan desa pemekaran dari Desa Tabongo Barat. Umumnya masyarakat di Kecamatan Batudaa dan Tabongo tergolong homogen, dan masih terkait hubungan keluarga yang cukup kuat antara satu sama lain.

Tabel 1. Luas Wilayah dan Kepadatan Penduduk

\begin{tabular}{llcc}
\hline Kecamatan & \multicolumn{1}{c}{ Desa } & $\begin{array}{c}\text { Luas Wilayah } \\
\left(\mathbf{K m}^{2}\right)\end{array}$ & $\begin{array}{c}\text { Jumlah } \\
\text { Penduduk }\end{array}$ \\
\hline Batudaa & Huntu & 4.18 & 1166 \\
\multirow{2}{*}{ Tabongo } & Pilobuhuta & 4.65 & 1614 \\
& Tabongo Barat & 1.93 & 2225 \\
& Mootinelo & 3.13 & 1519 \\
\hline
\end{tabular}

Sumber: BPS, Kabupaten Gorontalo dalam angka, 2017

\section{Penduduk Berdasarkan Tingkat Pendidikan}

Tingkat pendidikan dapat berpengaruh terhadap tingkat pengetahuan, sikap, perilaku, status sosial seseorang atau kelompok masyarakat. Berdasarkan pada tabel 2, rata-rata jumlah penduduk yang cenderung berpendidikan SD, tidak tamat SD, dan tidak/belum sekolah memiliki angka paling dominan di empat desa tersebut. Desa 
Motinelo memiliki jumlah paling banyak dibanding desa lainnya untuk kategori rendahnya tingkat pendidikan penduduk. Penduduk dengan tingkat pendidikan perguruan tinggi terbanyak yaitu terdapat di Desa Huntu Kecamatan Batudaa.

Tabel 2. Penduduk Berdasarkan Status Pendidikan

\begin{tabular}{llcccccc}
\hline Kecamatan & Desa & $\begin{array}{c}\text { Tidak/Belum } \\
\text { Sekolah }\end{array}$ & $\begin{array}{c}\text { Tidak } \\
\text { Tamat SD }\end{array}$ & $\begin{array}{c}\text { Tamat } \\
\text { SD }\end{array}$ & $\begin{array}{c}\text { Tamat } \\
\text { SMP }\end{array}$ & $\begin{array}{c}\text { Tamat } \\
\text { SMU }\end{array}$ & PT \\
\hline Batudaa & Huntu & 367 & 16 & 202 & 203 & 292 & 142 \\
\multirow{2}{*}{ Tabongo } & Pilobuhuta & 228 & 320 & 41 & 304 & 160 & 68 \\
& Tabongo Barat & - & - & - & - & - & - \\
& Mootinelo & 404 & 403 & 674 & 22 & 51 & 2 \\
\hline
\end{tabular}

Sumber: BPS, Kabupaten Gorontalo dalam angka, 2017

\section{Perkembangan Produksi Jagung dan Produktifitas Lahan}

Produksi jagung diwilayah Kecamatan Batudaa dan Tabongo secara umum menunjukan peningkatan kuantitas produksi yang semakin meningkat sejak tahun 2014 hingga tahun 2016. Namun secara khusus produktivitas jagung per hektar ternyata menunjukan angka yang semakin menurun sejak tahun 2014 hingga tahun 2016, terutama di Kecamatan Batudaa. Sedangkan produksi jagung di Kecamatan Tabongo ditahun 2015 juga secara umum menunjukan angka yang relative kecil dibandingkan Kecamatan Batudaa dengan rata-rata produksi hanya 4,7 ton per hektar. Padahal Kecamatan Tabongo memiliki jumlah luas panen terbesar dibandingkan Kecamatan Batudaa, namun belum mampu mencapai angka produktivitas hingga 5 ton per hektar.

Tabel 3. Luas Tanam, Luas Panen, dan Produksi Jagung

\begin{tabular}{lccccc}
\hline Kecamatan & Tahun & $\begin{array}{c}\text { Luas Tanam } \\
\text { (Ha) }\end{array}$ & $\begin{array}{c}\text { Luas Panen } \\
\text { (Ha) }\end{array}$ & $\begin{array}{c}\text { Produksi } \\
\text { (ton) }\end{array}$ & $\begin{array}{c}\text { Rata-rata } \\
\text { Produksi / Ha }\end{array}$ \\
\hline Batudaa & 2014 & - & 1.017 & 5.862 & 5.76 \\
& 2015 & - & 1.010 & 5.658 & 5.60 \\
\multirow{3}{*}{ Tabongo } & 2016 & - & 1.207 & 6.037 & 5.01 \\
& 2014 & 2.172 & 2.352 & 1.406 & 0.59 \\
& 2015 & 2.352 & 2.452 & 11.529 & 4.70 \\
\hline
\end{tabular}

Sumber: BPS, Kabupaten Gorontalo dalam angka, 2017

\section{KONDISI SOSIAL EKONOMI PETANI JAGUNG SEBELUM MENJADI MITRA IGROW}

\section{Petani Jagung Berdasarkan Status Kepemilikan dan Luas Lahan}

Lahan merupakan elemen kunci bagi petani dalam aktivitas pertaniannya. Dalam mengelola lahan pertanian, mayoritas petani jagung mitra iGrow di Kecamatan Batudaa dan Tabongo dengan jumlah 64,28 \% mengelola lahan milik pribadi, sedangkan 35,72 \% hanya mengelola lahan milik orang lain atau berstatus sebagai petani penggarap (Gambar 1).

Berdasarkan kriteria luas lahan (Gambar 1), mayoritas lebih dari $85 \%$ rata-rata memiliki luas lahan atau menggarap lahan lebih dari 2 hektar. Namun luas lahan petani yang terdata dalam mitra iGrow hanya berkisar pada 0,25 hingga 1 hektar. Hal ini disebabkan belum terpenuhinya sebagian lahan milik petani berdasarkan kriteria lahan yang dipersyaratkan oleh iGrow. 

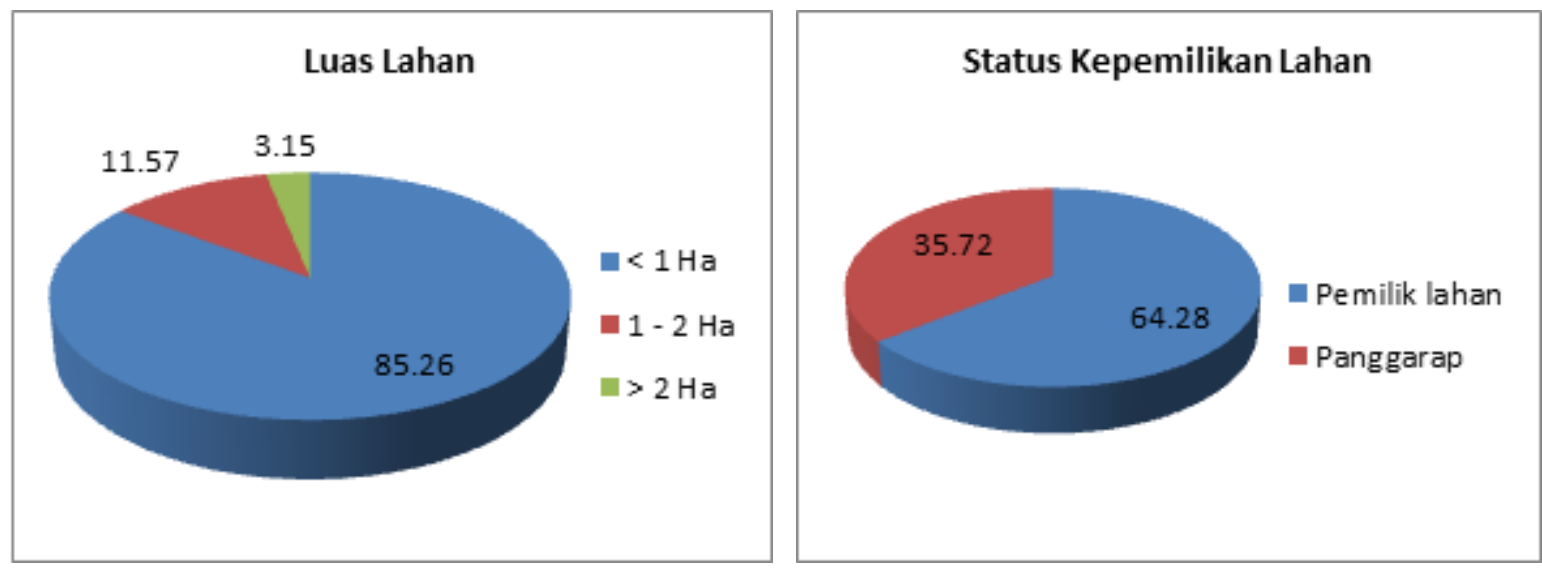

Gambar 1. Presentase Status Kepemilikan dan Luas Lahan Sumber: Data primer diolah, 2019

\section{Petani Jagung Berdasarkan Pekerjaan}

Status pekerjaan sebagai petani jagung di Kecamatan Batudaa dan Tabongo, mayoritas merupakan pekerjaan utama petani. Disamping sumber penghasilan utama sebagai petani jagung, rata-rata petani jagung juga memiliki sumber penghasilan sampingan yaitu dagang, petani kelapa, aparatur desa, serta buruh. Namun besaran penghasilan dari pekerjaan sampingan petani kadang sedikit lebih banyak dibandingkan penghasilan dari pekerjaan utama sebagai petani jagung. Fenomena ini lebih banyak ditemukan pada petani mitra yang memiliki pekerjaan sampingan sebagai pedagang.

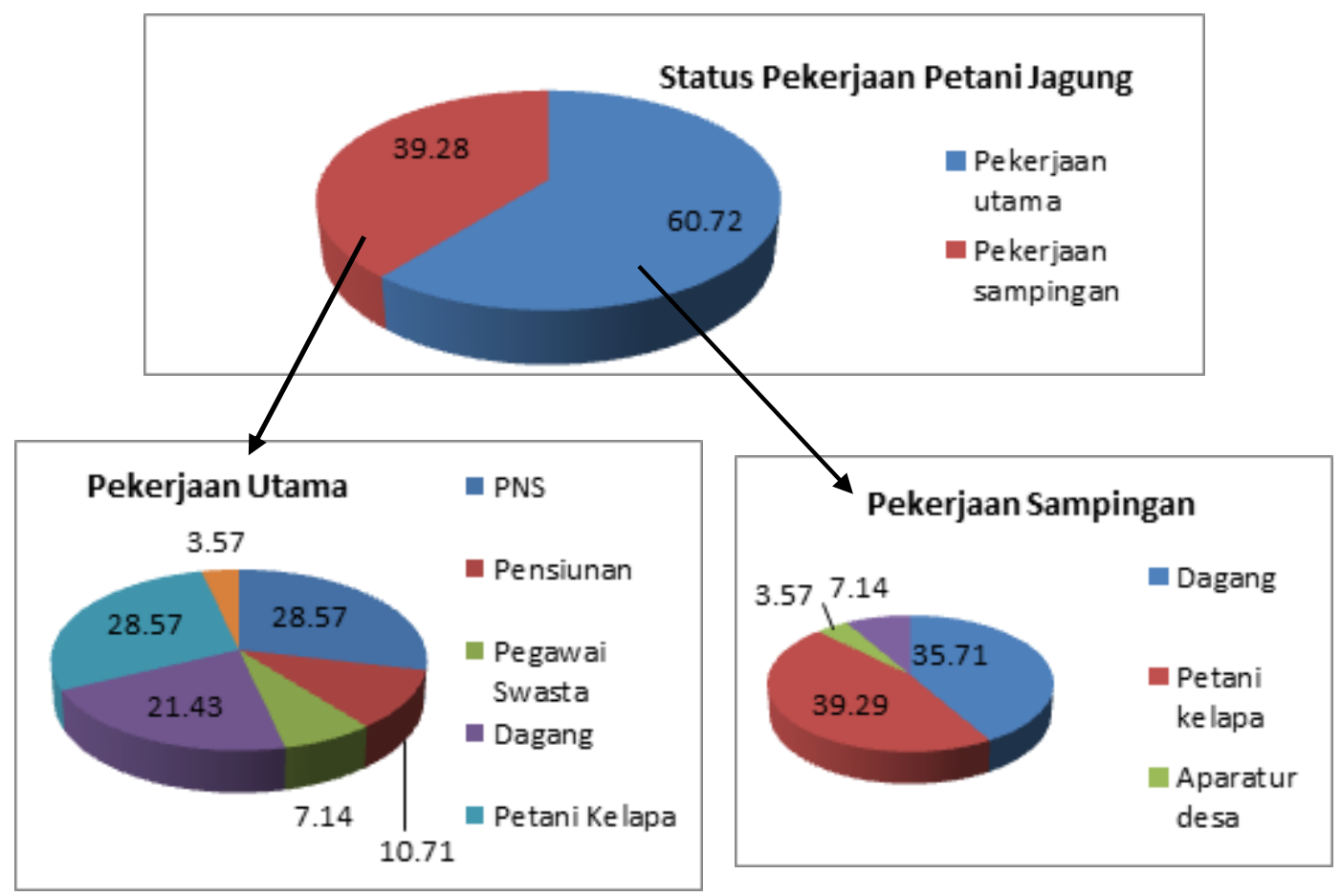

Gambar 2. Status Pekerjaan Petani Jagung

Sumber : Data primer diolah, 2019 
Profesi sebagai petani jagung hanya menjadi profesi sampingan oleh mereka (petani) yang rata-rata memiliki pekerjaan utama sebagai PNS / Pensiunan, pegawai swasta, pedagang dan petani kelapa. Rata-rata petani tersebut merupakan pemilik lahan, namun hanya sebagian kecil dari mereka yang turut mengolah / menggarap sendiri lahannya.

\section{Petani Jagung Berdasarkan Status Penduduk Miskin Sebelum Kemitraan}

Mayoritas $71,42 \%$ petani mitra iGrow merupakan penduduk miskin. Salah satu indikator yang terlihat sebagai penduduk miskin yaitu mereka (petani) sebagai penerima berbagai program bantuan penduduk miskin dari pemerintah. Jenis bantuan yang diterima oleh petani jagung seperti beras miskin (raskin), bantuan listrik gratis, rumah layak huni, bantuan pendidikan dan kesehatan. Selain program bantuan sosial, petani juga menerima bantuan disektor pertanian berupa saprodi (pupuk dan benih jagung). Dari aspek tanggungan keluarga, lebih dari $75 \%$ petani memiliki beban tanggungan keluarga antara 4 sampai 6 jiwa.
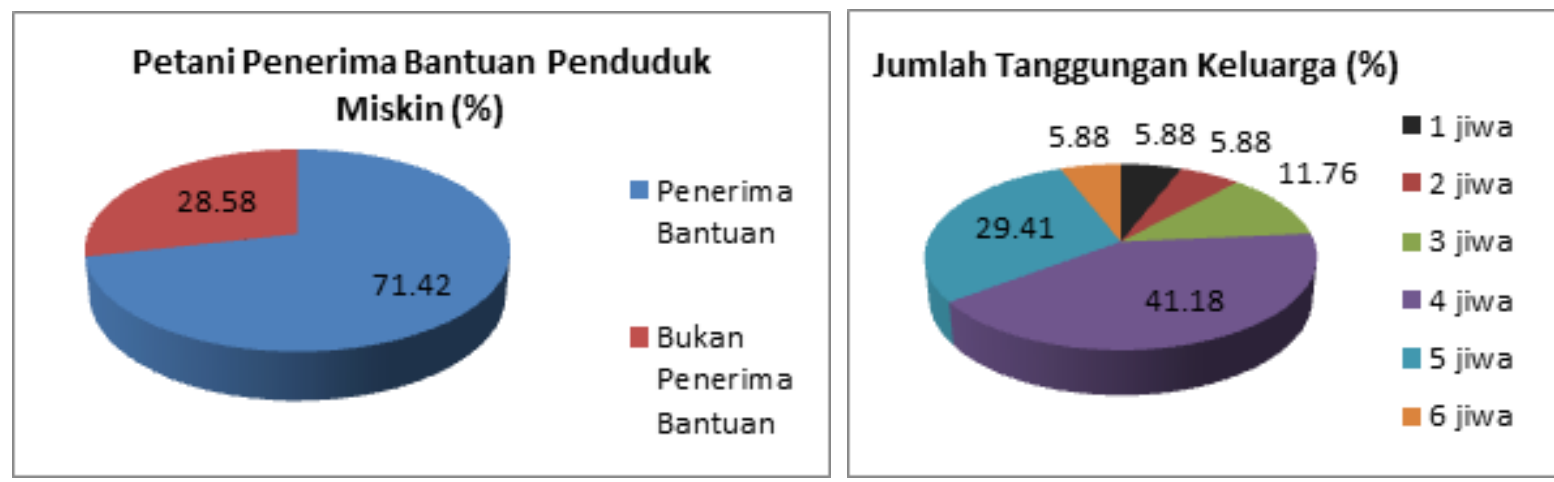

Gambar 3. Petani Status Penduduk Miskin

Sumber : Data primer diolah, 2019

\section{Produktivitas lahan Sebelum Kemitraan}

Berdasarkan hasil wawancara terhadap petani mitra yang tersebar di Kecamatan Tabongo dan Batudaa terkait produksi jagung, maka diperoleh kisaran rata-rata produksi jagung adalah 1.75 ton dengan rata-rata luas lahan $0.63 \mathrm{Ha}$. Jika dikonversi dalam satuan 1 hektar, maka total rata-rata produktivitas jagung dalam 1 hektar adalah 2,79 ton. Data tersebut merupakan data rata-rata panen terakhir petani sebelum menjadi mitra iGrow. Merosotnya hasil panen terakhir disebabkan faktor kurangnya curah hujan serta keterbatasan petani dalam akses sarana produksi seperti pupuk, benih dan peralatan. Berdasarkan wawancara dengan petani, produksi normal jagung biasanya berkisar pada angka 4 ton per hektar.

Jumlah produksi petani jagung di Kecamatan Batudaa dan Tabongo dapat dikatakan masih dibawah produksi yang semestinya dapat mencapai 6 hingga 7 ton per hektar. Untuk dapat mencapai hasil maksimal, tidak hanya keterbatasan petani dalam produksi yang perlu dituntaskan, namun aspek wawasan dan pengetahuan usahatani juga perlu perlu dibentuk. Peran pemberdayaan perusahaan mitra terhadap petani sekiranya dapat mendongkrak petani untuk mencapai hasil maksimal. 
Tabel 4. Produksi dan Luas Lahan

\begin{tabular}{ccc}
\hline $\begin{array}{c}\text { Rata-rata panen petani } \\
\text { (sebelum kemitraan) }\end{array}$ & $\begin{array}{c}\text { Rata-rata luas } \\
\text { lahan }\end{array}$ & $\begin{array}{c}\text { Jumlah petani } \\
(\%)\end{array}$ \\
\hline$<1$ ton & $0.26 \mathrm{Ha}$ & 11.76 \\
1 ton & $0.49 \mathrm{Ha}$ & 35.29 \\
2 ton & $0.71 \mathrm{Ha}$ & 38.24 \\
3 ton & $0.78 \mathrm{Ha}$ & 5.88 \\
$>3$ ton -6 ton & $1.49 \mathrm{Ha}$ & 8.82 \\
\hline Rata-rata Produksi $=$ & $\begin{array}{c}\text { Rata-rata lahan } \\
\mathbf{1 . 7 5} \text { ton }\end{array}$ & $\mathbf{1 0 0 . 0 0}$ \\
\hline
\end{tabular}

Berdasarkan data tersebut maka rata-rata produktivitas lahan jagung jika dikonversi dalam satuan 1 hektar adalah : 2.79 ton. Data ini merupakan hasil panen terakhir sebelum tergabung dalam kemitraan iGrow.

Sumber : Data primer, diolah 2019

Rendahnya produktivitas jagung per hektar lahan, meurut petani disebabkan karena berbagai faktor keterbatasan dan kendala yang dialami petani. Berbagai kendala yang dikemukakan petani dalam kegiatan usahatani jagung yaitu :

Tabel 5. Kendala-kendala dalam Usahatani Jagung

\begin{tabular}{lr}
\hline $\begin{array}{l}\text { Kendala dan keluhan petani terkait kegiatan } \\
\text { usahatani jagung sebelum kemitraan }\end{array}$ & \multicolumn{1}{c}{$\%$} \\
\hline 1. Keterbatasan dalam modal financial usahatani & 35,29 \\
2. Minimnya peralatan pertanian & 23,53 \\
3. Sulitnya pengelolaan lahan sebelum masa tanam & 17,65 \\
4. Jumlah bibit dan pupuk digunakan masih terbatas & 17,65 \\
5. Sering gagal panen & 11,76 \\
6. Tingginya biaya tanam dan pasca panen & 5,88 \\
7. Keterbatasan dalam pengelolaan dana usahatani & 5,88 \\
\hline Sumber: Data primer, diolah 2019
\end{tabular}

\section{Pendapatan Usahatani Jagung Sebelum Kemitraan}

1 Penerimaan usahatani jagung.

- Bardasarkan data di atas, rata-rata produksi jagung petani adalah 1,75 ton per 0.63 hektar dengan rata-rata harga pembelian jagung ditingkatan pedagang sebesar $\mathrm{Rp} 3800$ / kg, maka rata-rata total penerimaan petani jagung adalah 1.753 $\mathrm{kg} \times \mathrm{Rp} 3800=\operatorname{Rp} 6.672 .800$.

- Jika dikonversi dalam satuan 1 hektar, maka rata-rata penerimaan petani adalah 2.79 ton $\times$ Rp $3800=\mathbf{R p} \mathbf{1 0 . 6 0 2 . 0 0 0} /$ hektar

\section{Pendapatan usahatani jagung}

Sebelum memperoleh besaran pendapatan petani jagung, maka rincian total biaya yang dibelanjakan petani pada satuan lahan 0,63 hektar yang terdiri dari variable cost (biaya veriabel) dan fixed cost (biaya tetap).

Berdasarkan Tabel 6, diperoleh rata-rata total biaya yang dikeluarkan petani jagung dalam satu musim tanam sebesar Rp. 4.581.000. Estimasi biaya yang sebenarnya bisa lebih besar dari angka tersebut, dikarenakan beberapa komponen biaya seperti pada biaya penyusutan alat, pajak lahan, tenaga kerja dalam keluarga, sewa lahan, biaya transportasi, dan biaya pasca panen, tidak termasuk dalam estimasi biaya oleh petani. 
Tabel 6. Estimasi Rata-rata Biaya Versi Petani Jagung

\begin{tabular}{|c|c|c|c|}
\hline Fixed cost (biaya tetap) & Jumlah & Satuan (Rp) & Jumlah biaya (Rp) \\
\hline Pajak lahan & & - & - \\
\hline Biaya tenaga kerja dalam keluarga & & - & - \\
\hline Sewa lahan & & - & - \\
\hline Biaya penyusutan alat & & - & - \\
\hline Jumlah & & 0 & 0 \\
\hline Variabel cost (biaya variable) & & & Jumlah biaya \\
\hline Biaya benih & 5 sak & 78.000 & 390.000 \\
\hline \multicolumn{4}{|l|}{ Biaya pupuk } \\
\hline Úrea & $100 \mathrm{~kg}$ & 90.000 & 180.000 \\
\hline Ponska & $100 \mathrm{~kg}$ & 115.000 & 230.000 \\
\hline \multicolumn{4}{|l|}{ Biaya pestisida } \\
\hline Calaris & $5 \times 500 \mathrm{ml}$ & 175.000 & 875.000 \\
\hline Noxon & 2 liter & 58.000 & 116.000 \\
\hline \multicolumn{4}{|l|}{ Biaya tenaga kerja luar keluarga } \\
\hline Pengolahan tanah & Paket & 750.000 & 750.000 \\
\hline Penanaman & 8 HKSP & 60.000 & 480.000 \\
\hline Pemupukan & 6 HKSP & 60.000 & 360.000 \\
\hline Pemberantasan hama penyakit & 6 HKSP & 60.000 & 360.000 \\
\hline Panen & 14 HKSP & 60.000 & 840.000 \\
\hline Biaya Transportasi & - & - & 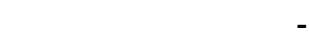 \\
\hline Biaya pasca panen & - & - & \\
\hline Jumlah & & & 4.581 .000 \\
\hline $\begin{array}{l}\text { Total biaya } \\
\text { (fixed cost + variable cost) }\end{array}$ & & & 4.581 .000 \\
\hline
\end{tabular}

Sumber: Data primer, diolah 2019

3. Pendapatan bersih petani

- Berdasarkan perhitungan rata-rata total penerimaan dikurangi total biaya petani jagung dalam rata-rata luas 0.63 hektar lahan, maka besaran pendapatan bersih petani yaitu Rp. 6.672.800 - Rp 4.581.000 = Rp. 2.091.800.

- Jika dikonversi pada luas lahan 1 hektar, maka rata-rata total pendapatan bersih petani jagung dalam 1 hektar yaitu = Rp. 3.332.265.

Sebagian petani memiliki rata-rata pendapatan sedikit lebih besar dari rata-rata pendapatan bersih tersebut, yang disebabkan sebagian petani jagung memperoleh bantuan / subsidi benih dan pupuk melalui wadah kelompok tani. Berikut merupakan jumlah petani yang memperoleh bantuan / subsidi benih dan pupuk.
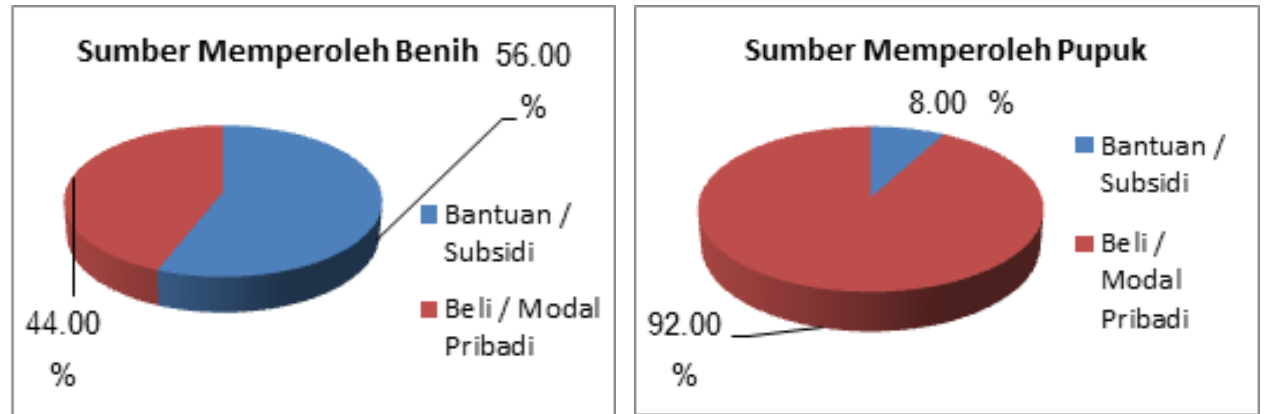

Gambar 4. Sumber Perolehan Benih dan Pupuk Sumber: Data primer diolah, 2019 


\section{Produksi dan Pemasaran Jagung}

Dalam aspek pemasaran, rata-rata mayoritas petani menjual jagung kepada pedagang besar yang berada diwilayah Kota Gorontalo. Selebihnya petani menjual jagung kepada pedagang pengumpul dengan konsekwensi harga yang relative lebih rendah. Harga jagung yang diperoleh petani rata-rata berkisar antara Rp 3400 hingga pada harga tertinggi Rp 5200 / Kg, dengan kadar air tertentu.

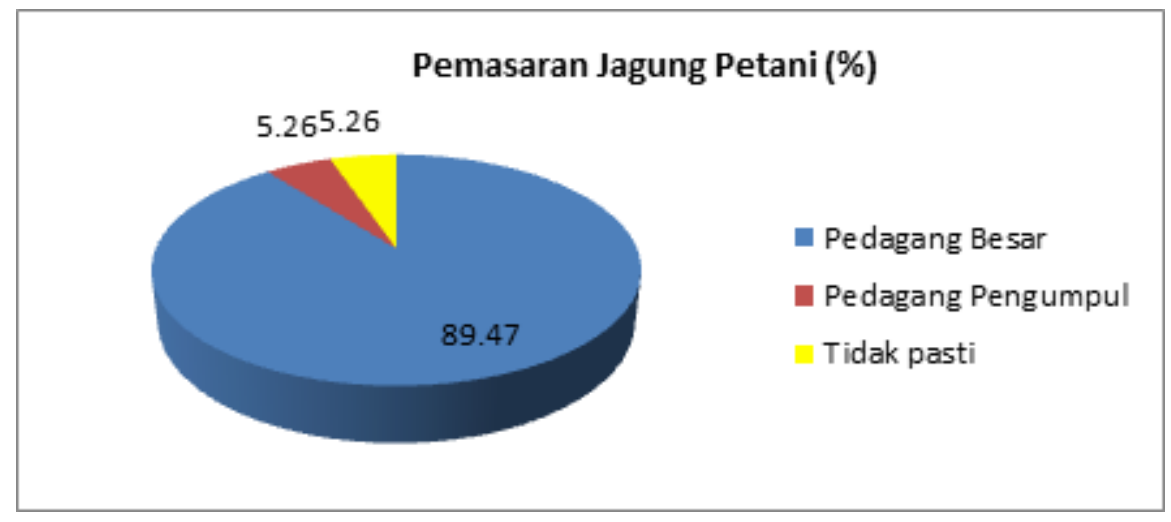

Gambar 5. Pemasar Jagung Petani

Sumber: Data primer diolah, 2019

Pola produksi dan pemasaran sebelum kemitraan dilakukan dengan model konvensional, dimana manajemen dikelola penuh oleh petani, namun faktor keterbatasan modal, input produksi, dan pengetahuan tetap menjadi hambatan klasik bagi petani.

Melalui jalinan kemitraan maka keterbatasan modal, input produksi serta faktor pengetahuan yang selalu dirasakan oleh petani dapat difaslitasi dan dilakukan pendampingan oleh iGrow. Demikian pula pada aspek pemasaran, iGrow tidak mengikat petani harus menjual hasil panen kepada iGrow, namun memberikan pilihan yang memungkinkan petani dapat memilih untuk memasarkan kepada pihak lain dengan tingkat harga yang sesuai.

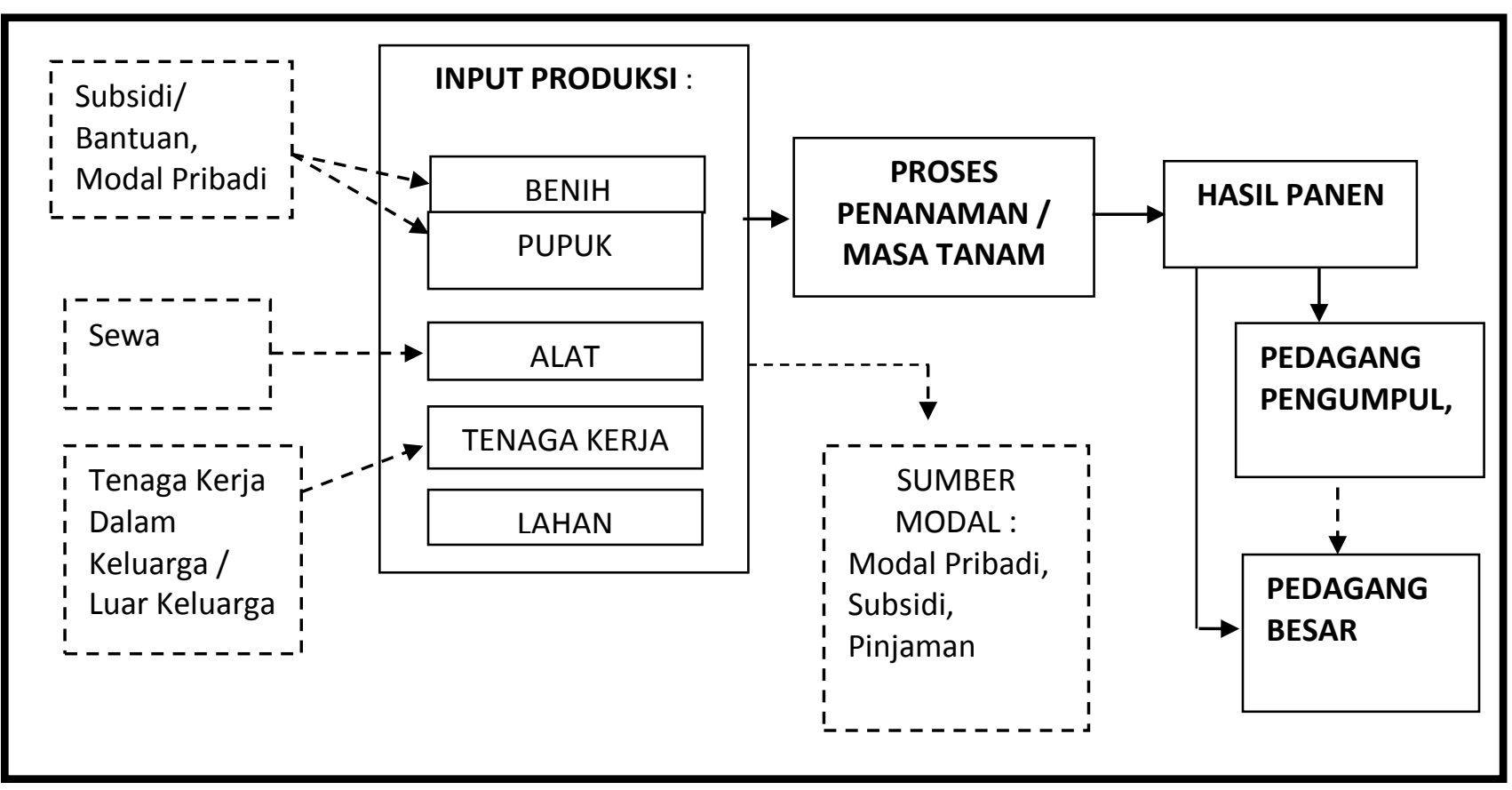

Gambar 6. Pola Produksi dan Pemsaran Sebelum Kemitraan Sumber: Data primer, diolah 2019 


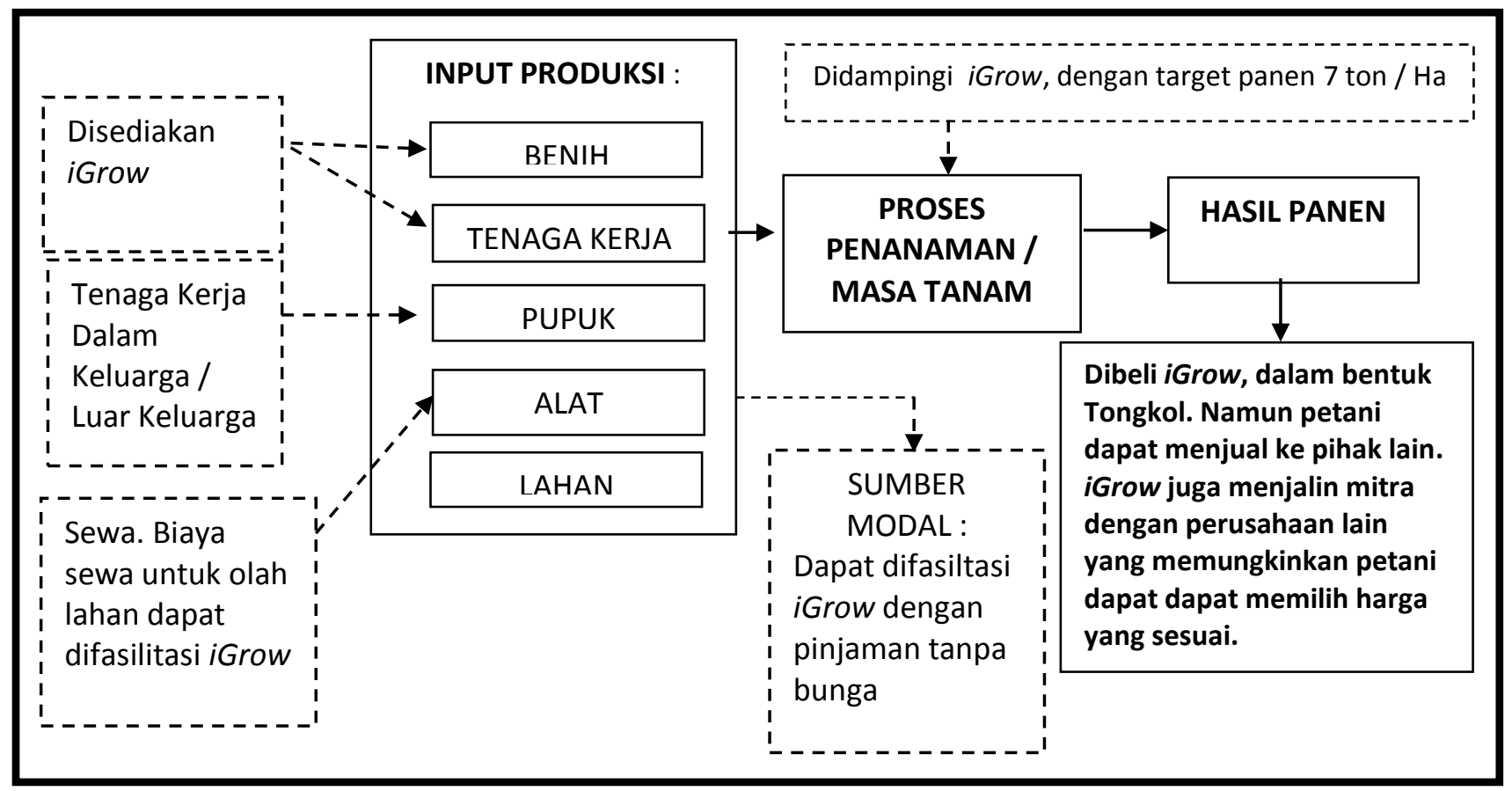

Gambar 7. Alur Produksi dan Pemasaran Dengan Pola Kemitraan iGrow Sumber: Data primer, diolah 2019

\section{Tanggapan Petani Terhadap Kemitraan Kerja Sama}

Umumnya sebagian besar petani yang tercatat sebagai petani mitra iGrow di Kecamatan Batudaa dan Tabongo memberikan respon yang baik dengan adanya kemitraan.

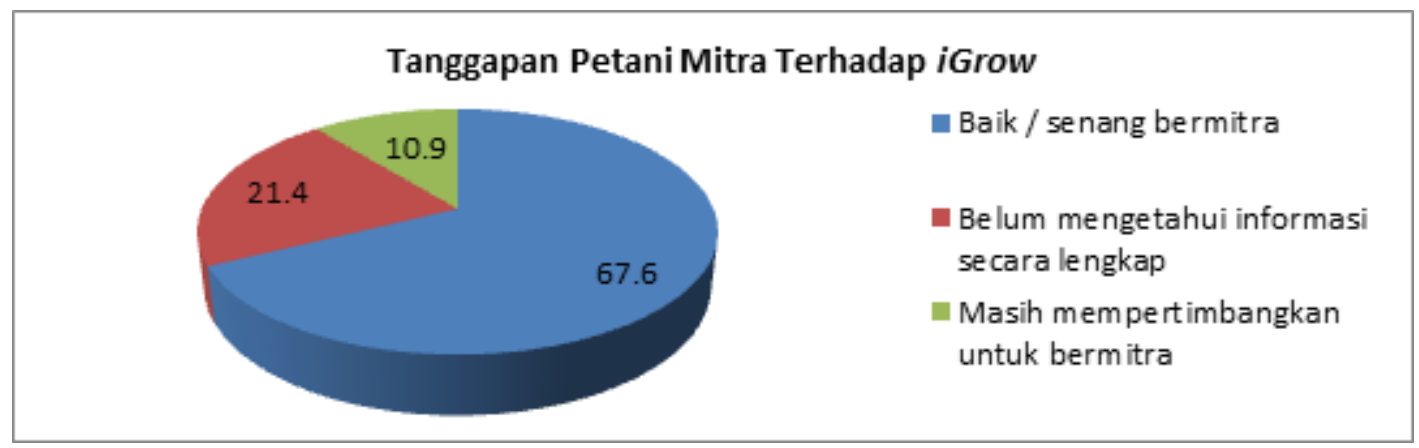

Gambar 8. Perbandingan Tanggapan Petani terhadap iGrow

Sumber: Data primer diolah, 2019

Petani tertarik dengan model kemitraan yang ditawarkan oleh iGrow, setetalah dilakukan sosialisasi kepada petani jagung tentang pola kemitraan dengan iGrow yang difasilitasi oleh pemerintah melalui BAPPEDA Provinsi Gorontalo. Meskipun masih dalam tahap awal, sebagian besar petani dapat memahami bahwa kerja sama dengan pihak iGrow akan memberikan banyak manfaat bagi petani terutama dalam usahatani jagung. Beberapa point penting dan positif yang dikemukaan terkait manfaat kerja sama petani jagung dengan iGrow yaitu : 
1. Akses terhadap permodalan menjadi lebih mudah.

2. Pengembalian modal setelah panen tidak dikenakan bunga.

3. Akses terhadap benih dan pupuk menjadi lebih mudah dari biasanya karena difasilitasi oleh iGrow.

4. Peluang petani untuk mendapatkan harga pasar yang lebih baik menjadi terbuka lebar, sebab petani tidak terikat untuk menjual hasil panen.

5. Peluang mendapatkan pendapatan lebih besar, karena beberapa komponen biaya dapat dikurangi seperti biaya pasca panen. Petani dapat memasarkan jagung hasil panen dalam bentuk tongkol, sehingga tidak harus menambah biaya perontokan/ rotor.

6. Program pendampingan petani cukup intensif dari pihak iGrow, sehingga petani dapat memperoleh wawasan dan pengetahuan baru.

Terlepas dari bagaimana upaya pemerintah untuk memberdayakan petani melalui kemitraan, petani yang cenderung memiliki pemikiran yang awam tentang bagaimana menjalin kemitraan hanya memiiliki satu harapan utama yaitu dapat merubah taraf hidup yang lebih sejahtera.

\section{SIMPULAN}

Rendahnya produktivitas jagung oleh petani di Kabupaten Gorontalo sebelum kemitraan yang rata-rata hanya 2.79 ton per hektar lahan, disebabkan karena berbagai faktor keterbatasan dan kendala yang dialami petani. Berbagai kendala utama petani dalam kegiatan usahatani jagung yaitu terbatasnya modal, terbatasnya input produksi (bibit /pupuk) minimnya peralatan produksi, pengolahan lahan, tingginya biaya produksi, pengelolaan dana/keuangan usaha tani dan seringnya gagal panen. Fakta ini berimbas pada pendapatan bersih petani jagung yang rata-rata hanya mencapai Rp. 3.332.265 / $\mathrm{Ha}$. Jumlah pendapatan bersih petani jagung yang relative kecil cukup menjadi alasan bagi mayoritas petani jagung yang masih berstatus penduduk miskin. Peran pemerintah Provinsi Gorontalo dengan menghadirkan pihak iGrow untuk menjalin kemitraan dengan petani jagung di Kabupaten Gorontalo dengan sasaran pokok pemberdayaan petani mendapatkan tanggapan positif dari sebagian besar petani jagung. Program yang ditawarkan melalui kemitraan dengan iGrow dinilai dapat menjawab persoalan-persoalan petani selama ini.

Kedepannya pola kemitraan antara petani jagung dan iGrow akan dievaluasi terkait tingkat keberhasilan serta perubahan nyata taraf ekonomi petani setelah bermitra dengan iGrow. Penelitian ini akan berlanjut pada tahap II setelah kemitraan petani jagung dengan iGrow selesai masa kontrak. Pemerintah Provinsi Gorontalo diharapkan dapat secara intensif untuk memantau berjalannya program. Keberhasilan program kemitraan ini akan menjadi pertimbangan pemerintah di wilayah lain untuk menerpkan program kemitraan.

\section{DAFTAR PUSTAKA}

Arikunto, Suharsimi. 2006. Metodelogi penelitian. Yogyakarta: Bina Aksara.

Badan Pusat Statistik. 2017. Kabupaten Gorontalo Dalam Angka. www.bps.go.id

BAPPEDA Provinsi Gorontalo. 2017. Kajian Kemiskinan Menurut Tipologi Wilayah di Provinsi Gorontalo.

BAPPEDA Provinsi Gorontalo. 2019. Kemitraan Petani Jagung : Pemprov Menggandeng UNDP dan i-Grow. bappeda.gorontaloprov.go.id

iGrow Asia, 2020. https://igrow.asia/page 
Lubis, Ernayanti. 2015. https://www.academia.edu/30373783/. Penelitian Deskriptif (kualitatif)

Hidayat, T., Yulida, R., dan Rosnita, Rosnita. 2017. Karakteristik Petani Padi Peserta Program Upaya Khususpadi Jagung Kedelaiupsus Pajale Di Desa Ranah Baru Kecamatan Kampar Kabupaten Kampar. JOM Faperta UR, 4(1), 1-12

Soekartawi. 2002. Analisis Usahatani. Jakarta : Raja Grafindo Persada 